\title{
A RESPONSABILIDADE EXTRACONTRATUAL DO ESTADO E O PRINCÍPIO DA PROPORCIONALIDADE: VEDAÇÃO DE EXCESSO E DE OMISSÃO
}

\author{
JUAREZ FrEITAS*
}

\begin{abstract}
1. Introdução; 2. O Princípio da Proporcionalidade: Vedação de Excessos e de Omissões; 3. Responsabilidade Extracontratual do Estado e o Princípio Proporcionalidade. Não se admite o Estado Segurador Universal, tampouco o Estado Omisso; 4. Conclusões
\end{abstract}

\section{Introdução}

A doutrina da responsabilidade extracontratual do Estado precisa ser reequacionada para, a um só tempo, incentivar o cumprimento das tarefas estatais defensivas e positivas e reparar os danos juridicamente injustos. Trata-se de duplo movimento, que consiste em assimilar a proporcionalidade como proibição de excessos e vedação de inoperância ou injustificável fuga dos deveres objetivamente estabelecidos.

É, portanto, em sintonia com o princípio constitucional da proporcionalidade, para além das movediças disputas semânticas, que o Estado, doravante, precisa responder objetivamente pelos danos causados a terceiros por seus agentes, nessa qualidade, claro que admitidas as excludentes, a saber, a culpa exclusiva da vítima, a culpa concorrente (excludente parcial), o ato ou fato exclusivo de terceiro (excludente, em regra), a força maior irresistível, o caso fortuito (desde que não atribuível a razões internas) e a impossibilidade motivada do cumprimento do dever (hipótese nova, proposta no presente estudo). Noutras palavras, a responsabilidade extracontratual do Estado pode ser traduzida como a obrigação de reparar ou compensar os

* Professor Titular e Coordenador do Mestrado e do Doutorado em Direito da PUCRS, Professor de Direito Administrativo da UFRGS e da Escola Superior da Magistratura-AJURIS, Presidente do Instituto Brasileiro de Direito Administrativo. Coordenador do Grupo de Pesquisa sobre Interpretação Constitucional no Pós-Graduação em Direito da PUCRS, Pesquisador Associado na Universidade de Oxford, Advogado, Consultor e Parecerista.

R. Dir. Adm.,

Rio de Janeiro, 241: 21-37,

Jul./Set. 2005 
danos materiais e imateriais causados a terceiros por ação ou omissão desproporcional e antijurídica, fazendo-se obrigatória, nos casos de culpa ou dolo, a regressiva contra o agente.

Eis o argumento-chave: o Estado brasileiro precisa ser responsável pela eficácia direta e imediata dos direitos fundamentais, já em suas obrigações negativas, já em suas dimensões prestacionais. Será, nessa perspectiva, proporcionalmente responsabilizável, tanto por ações como por omissões, admitida a inversão do ônus da prova da inexistência do nexo causal a favor da suposta vítima.

Em confluência com a assertiva anterior, convém, desde logo, frisar que a quebra nuclear da proporcionalidade faz antijurídica - com todos os efeitos daí decorrentes - a ação ou a omissão estatal causadora de dano juridicamente injusto. Seguindo tal raciocínio, as condutas comissivas, uma vez presente o nexo de causalidade com o evento danoso, serão sempre antijurídicas, se e quando reprováveis à luz da proporcionalidade.

Ainda que não seja errôneo asseverar que a responsabilidade extracontratual das pessoas jurídicas de direito público e de direito privado prestadoras de serviços públicos independe de licitude em sentido estrito, bem mais adequado, nessa altura, é reconhecer o pressuposto imprescindível da violação à proporcionalidade para a configuração do dano indenizável. Bem observadas as coisas, unicamente de tal violação nasce o dever reparatório ou compensatório.

Sem diferença de fundo, assertiva idêntica pode ser efetuada em relação às condutas omissivas. A omissão causa o dano injusto que se consuma pelo não-cumprimento do dever estatal incontornável. Não há, com a devida vênia, nada substancial que justifique o tratamento radicalmente distinto entre ações e omissões, no modelo constitucional brasileiro: a responsabilidade é proporcional, seja por ações, seja por omissões danosas causadas por agentes das pessoas jurídicas de direito público e de direito privado prestadoras dos serviços de titularidade do Poder Público.

Nesse quadro, a tendência européia de tecer críticas e restrições à teoria da responsabilidade objetiva da Administração Pública(v.g., na Espanha ${ }^{1}$ ), repousa na pré-compreensão de queo Estado não deve ser conduzido às raias do papel de segurador ilimitado. Trata-se de preocupação mais do que salutar, dotada de alta dose de razão.

No entanto, a responsabilidade extracontratual do Estado pode ser considerada objetiva, semque, para tanto, tenha-se de acolher qualquer hipótese de dano indenizável que não se revelar antijurídico e injusto. $O$ vantajoso, nesse prisma teórico, é que atende à salutar preocupação com a abusiva e inaceitável responsabilização integral, sem resvalar para o abandono da responsabilidade objetiva, louvando-se numa noção de nexo proporcional, que impele o Estado a cumprir suas indeclináveis tarefas positivas ${ }^{2}$ e negativas. Tudo no intuito de melhor proteger a intersubjetiva

1 Vide, a propósito, o artigo "Novas orientações doutrinárias sobre a Responsabilidade Patrimonial da Administração Pública" de Jaime Rodríguez-Araña in Revista Interesse Público, n. 29, 2005. 2 Vide Michael Sachs in Verfassungsrecht II - Grundrechte, $2^{\star}$ ed., Berlin/Heidelberg, Springer, 2003. 
dignidade, bem como respeitar e fazer respeitar a intangibilidade nuclear dos direitos fundamentais.

Formado o liame em tais moldes, não há, a rigor, motivo para perquirir sobre culpa ou dolo do agente, nas condutas comissivas ou omissivas (não apenas as "voluntárias", para utilizar a expressão contida no Código Civil), examinada tão-só a presença da antijuridicidade e a sua extensão, mais ou menos grave, no tocante à violação da proporcionalidade, ora pelo cometimento de excessos, ora pela perpetração — não menos nociva - de omissões.

Numa hipótese e noutra, desde que ocorrida a violação, cristaliza-se o dano injusto e indenizável ${ }^{3}$, nada importando que a conduta do agente seja catalogada como lícita em sentido estrito, sem prejuízo da responsabilização do agente, que será invariavelmente subjetiva, aferida em ação regressiva ou pela antecipação dela, via denunciação da lide. ${ }^{4}$

Lógico que a abordagem proposta não representa, nem remotamente, adesão à teoria do risco integral, pois admite a invocação das referidas causas excludentes, inclusive a impossibilidade justificada do cumprimento de dever. Conseqüentemente, uma vez admitidas causas de exclusão, o Estado não se converte em pródigo e autofágico “segurador universal”, tampouco em garantidor bizarro dos riscos exclusivamente imputáveis a particulares.

Reorientada pela diretriz da proporcionalidade, a teoria do risco administrativo enseja concepção moderada de responsabilidade extracontratual do Estado, ${ }^{5}$ avessa a atalhos heurísticos perigosos ${ }^{6}$, bem como superadora da visão naturalística do liame causal e das falácias que confundem meras correlações com a causalidade.

Assentadas tais idéias, urge desdobrá-las na releitura da responsabilidade extracontratual do Estado sob o influxo forte do princípio da proporcionalidade, que veda, concomitantemente, os excessos e as omissões ("aliud agere" ou "nihil facere").

3 Sobre as características do dano indenizável, vide Jean Rivero in Direito Administrativo. Coimbra: Almedina, 1981, pp. 314-315. A respeito da natureza pecuniária do ressarcimento, vide Renato Alessi in Sistema Istituzionale di Diritto Amministrativo, Milano: Dott. A. Giuffrè Editore, 1960. A respeito, ainda, do dano indenizável, convém meditar sobre os enunciados formulados por Yussef Cahali in Responsabilidade Civil do Estado. $2^{2}$ ed., São Paulo: Malheiros, 1996 (pp. 49-69). Note-se que, em seu primeiro enunciado, embora aluda à noção de falha de serviço, enfatiza a deficiência como causa e, no último, já explicita aspecto relevante do princípio da proporcionalidade.

4 Inafastável o dever de promover (presente culpa ou dolo) a regressiva. Na órbita federal, vide a Lei 4.619/65. De outra parte, mostra-se inconstitucional qualquer tentativa de responsabilização objetiva do agente público, em sentido amplo.

5 Útil enfatizar que há significativas dintinçōes na disciplina da responsabilidade extracontratual e da contratual, no campo do Direito Administrativo. O presente estudo versa apenas sobre a responsabilidade extracontratual.

6 Vide Daniel Kahneman, Paul Slovic e Amos Tversky (editores) in Judgment under Uncertainty: Heuristics and Biases. Cambrige: Cambridge University Press, 1982. 
O princípio da proporcionalidade determina que o Estado não deve agir com demasia, tampouco de modo insuficiente, na consecução dos seus objetivos. Desproporções - para mais ou para menos - caracterizam violações ao princípio e, portanto, antijuridicidade. Para ilustrar, se a Administração Pública, à guisa de retirar de circulação alimentos deteriorados, destrói produtos sadios, incorre em violação por reprovável descomedimento. No extremo oposto, quando nãorespeita, quiçá por acrasia, a duração razoável do processo administrativo ${ }^{7}$ de licenciamento ambiental, quebra a proporção, agora por restar aquém documprimento do dever positivamente estabelecido.

A grave violação sucede em ambos os casos. No primeiro, ocorre excesso vedado e arbitrário; no segundo, tem-se a repulsiva inobservância do Estado no cumprimento de obrigação dele exigível. Do nexo causal ${ }^{8}$ direto e "imediato" (primeiro requisito) e do dano juridicamente injusto (segundo requisito), dimanam o dever reparatório ou compensatório, incumbindo o ônus da prova da não-formação do nexo causal ao Poder Público. ${ }^{9}$

Cumpre notar que o princípio da proporcionalidade não estatui simples adequação meio-fim. Para ser preciso, a violação à proporcionalidade ocorre, não raro, quando, na presença de valores legítimos a sopesar, o agente público dá prioridade a um em detrimento exagerado ou abusivo de outro.

Comum, entretanto, que haja sacrifícios aceitáveis na aplicação do Direito Público. O vício acontece na instauração do sacrifício iníquo. Não por mera coincidência, o princípio constitucional da proporcionalidade avulta justamente no cotejo de direitos fundamentais. ${ }^{10}$ Nesse passo, útil retomar um dos exemplos citados - a

7 Em colisão frontal com dispositivo trazido pela Emenda Constitucional 45, que nada mais faz do que explicitar o direito fundamental a processos administrativos e jurisdicionais efetivos.

8 Sobre o tema, vide a observação de Rubén H. Compagnucci de Caso in Responsabilidad civi] y relación de causalidad, Buenos Aires: Astrea, 1984, p. 23; "En el plano jurídico la relación causal es el nexo entre la acción humana y el resultado acaecido." E adiante, observa, com pertinência, na p. 28: "El análisis de la relación causal debe ser siempre anterior al de la culpabilidad", excercitando juízo de probabilidade in abstracto, num prognóstico objetivo (p.30).

9 Por essa razão de fundo é que entendo acertada (ainda que difira em relação à responsabilidade do agente, pois não acolho a tese da objetivação da culpa) a abordagem de Marçal Justen Filho in Curso de Direito Administrativo. São Paulo: Saraiva, 2005, pp. 796-799, no ponto relevante em que afirma a antijuridicidade como indispensável à responsabilização do Estado, bem como ao pretender o tratamento unitário para ações e omissões. Por sua vez, Celso Antônio Bandeira de Mello, a despeito de adotar posição diversa sobre responsabilidade do Estado por omissões (sustenta que é subjetiva, ainda que introduza distinção com as situações propiciatórias), aproxima-se um pouco mais dessa minha abordagem, ao efetuar mudança realizada na edição de 2005 , quando admite, para todos os casos de "falta do serviço", a presunção de culpa com inversão do ônus da prova (in Curso de Direito Administrativo, São Paulo: Malheiros, 2005, pp. 945-946).

10 Sobre a importância dos princípios constitucionais (em geral) para o Direito brasileiro, vide a belíssima contribuição de Luís Roberto Barroso in "Neoconstitucionalismo e Constitucionalização do Direito", Revista Interesse Público, 33, 2005. 
colisão entre o exercício do direito à propriedade e do direito à saúde ${ }^{11}:$ se, além da preservação da saúde, erradicar-se nuclearmente o direito à propriedade, em lugar da restrição adequada, consubstanciar-se-á o ato abusivo e indenizável. Outra ilustração: se, no processo administrativo disciplinar, aplicar-se a penalidade demissória, em situação na qual a punição menos severa revelar-se mais consentânea, verifica-se outra violação ao princípio da proporcionalidade, de molde a macular a aplicação da penalidade, sem que o Poder Judiciário, para coibir tal prática, tenha de invadir, de modo usurpatório, o impropriamente denominado mérito administrativo. ${ }^{12}$

Em nenhuma circunstância, um direito fundamental deve suprimir inteiramente outro na eventual colisão de exercícios. Apenas deve preponderar topicamente. A razão está em que os princípios nunca se eliminam, diferentemente do que sucede com as regras antinômicas e, ainda assim, por preponderância principiológica. O agente público, dito de outro modo, está obrigado a sacrificar o mínimo para preservar o máximo de direitos fundamentais.

Nesse prisma ${ }^{13}$, tal princípio, em suas duas facetas (vale recordar, a vedação de excessos e a proibição de inoperâncias ou omissões) revela-se deveras significativo em matéria de responsabilidade. "A fortiori", se se quiser que o Estado assegure a proteção efetiva do núcleo indisponível ${ }^{14}$ dos direitos fundamentais de todas as dimensões. ${ }^{15}$ Importa destacar, portanto, a positividade do princípio em tela. Positividade que também determina a sua vinculação a outros princípios de mesma estatura (ou "fundamentalidade"), tais como o da economicidade e o da igualdade. Adequadamente assimilado, o princípio da proporcionalidade não deixa de ser uma versão jurídica do "justo meio" de Aristóteles.

Em determinadas situações, faz a diferença entre a vida e a morte. Com efeito, tome-se, por sua atualidade, o caso emblemático do direito ao medicamento de uso contínuo. Afigura-se irretorquível que o carente, em nosso sistema, possui o direito de recebê-lo do Estado, que, ressal vada a impossibilidade motivada do cumprimento desse dever, precisa prestá-lo. E o tem feito, não raro, por pressão legítima de decisões judiciais, em razoável papel concretizador da eficácia direta e imediata de direito fundamental à vida. ${ }^{16}$

11 A rigor, a colisão não se dá entre os direitos fundamentais em si, desde que exercidos sem abusividade. Para uma abordagem mais aprofundada do tema, vide, por obséquio, o meu livro A Interpretação Sistemática do Direito. $4^{2}$ ed., São Paulo: Malheiros, 2004.

12 Vide o MS 7983, julgado pelo STJ, numa aplicação bem-sucedida do princípio da proporcionalidade.

13 Convido o leitor para conhecer minha abordagem do tema na obra O Controle dos Atos Administrativos e os Princípios Fundamentais. 3a ed. São Paulo: Malheiros, 2004.

14 Vide, em confluência, sobre a indisponibilidade dos direitos fundamentais, Marçal Justen Filho in ob.cit, p.45.

15 Vide Ingo Wofgang Sarlet in A Eficácia dos Direitos Fundamentais. Porto Alegre: Livraria do Advogado, 2003, pp.287-342, em notável abordagem da problennática dós direitos sociais na qualidade de direitos subjetivos a prestações.

16 Sobre o direito ao fornecimento de remédio, vide, para ilustrar, REsp 686.208-RJ. Rel. Min. Luiz Fux. Vide, ainda, o julgamento do REsp 699550. 
Convém sublinhar que a influência do princípio da proporcionalidade, no Direito Administrativo, deita raizes longínquas. Foi no contexto do "poder de polícia" que a proporcionalidade fez a sua primeira aparição no mundo jurídico moderno. ${ }^{17} \mathrm{Na}$ virada do século XIX para o século XX, Otto Mayer destacava que " $a$ condição da proporcionalidade, inerente a todas as manifestações do poder de polícia, deve produzir seu efeito" também quando se tratar de zelo pela boa ordem da coisa pública ("guter Stand des Gemeinwesens") ${ }^{18}$.

Na prática dos atos de "polícia administrativa", já então a conduta do Estado deveria ser a mais suave e branda possível, guardadas, como medida de intensidade, as exigências ditadas pelo interesse público. Ao disciplinar o exercício dos direitos à liberdade e à propriedade, o Estado só deveria lançar mão das medidas mais enérgicas como derradeira "ratio", pois ninguém poderia ser constrangido a suportar restrições acima do grau necessário à satisfação dos interesses superiores da comunidade. Exprimindo de modo sugestivo o âmago do princípio, Fritz Fleiner, fazendo coro a Walter Jellinek, proclamava: " a policia não deve utilizar canhōes para abater pardais" 19 .

Como se nota, nos albores da sistematização do Direito Administrativo, a doutrina operava com o clássico trinômio "lei-finalidade-proporcionalidade". Com a mesma energia que realçou a estrutura teleológica dos preceitos normativos (toda lei pressupõe uma finalidade), boa parte da doutrina aceitou, sem muito hesitar, que os fins inerentes às normas deveriam ser perseguidos dentro e nas fronteiras da proporcionalidade.

Mas suas virtudes benfazejas, a passo e passo, iluminaram outros segmentos do Direito, notadamente na seara constitucional. ${ }^{20}$ Uma das novas fronteiras desbrava-

17 Peter Badura in Staatsrechts. München: C. H. Beck'sche Verlagbuchhandlung, 1986, p. 84, assinala que o princípio da proporcionalidade, no início, estava ligado ao exercício do poder de polícia ("Der Grundsatz ist zuerst im Polizeirecht entstanden"), tendo, algum tempo depois, se transformado em limite geral à intervenção do Poder Executivo ("allgemeine Grenze des Einschreitens der Executive"). Ainda de acordo com Badura, as intervenções do Poder Público somente seriam consideradas legítimas ("rechtsmässig"), quando atendessem aos requisitos da necessidade ("Erforderlichkeit") e da proporcionalidade ("Proportionalität"), requisitos que se encontrariam fundidos debaixo da idéia de vedação de excessos ("iubermassverbots"). J. J. Gomes Canotilho corrobora essa avaliação histórica, ao escrever que "o principio da proporcionalidade dizia primi. tivamente respeito ao problema da limitação do poder executivo, sendo considerado como medida para as limitaçōes administrativas da liberdade individual. É com este sentido que a teoria do Estado o considera, já no séc. XVIII, como máxima suprapositiva, e que ele foi introduzido, no séc. XIX, no direito administrativo, como princípio geral do direito de polícia" in Direito Constitucional. Coimbra: Livraria Almedina, 1991, p. 386.

18 In Le Droit Administratif Allemand. Paris: V. Giard \& E. Brière, 1904, vol. II, p. 60: “..., la condition de la proporcionalitè, inhérente à toutes les manifestations du pouvoir de police, doit produire son effet".

19 In Institutionen des deutschen Verwaltungsrechts. Tübingen: Scientia Verlag Aalen. 1963, p. 404: "Die Polizei soll nicht mit Kanonen auf Spatzen schiessen".

20 Entre nós, vide, por todos, o capitulo sobre o princípio da proporcionalidade de Paulo Bonavides in Curso de Direito Constitucional. São Paulo: Malheiros Editores, 2004. 
das pela máxima do equilíbrio entre meios e fins foi a da produção legislativa. Em meados do século passado, Ernst Forsthoff noticiava que o princípio da proporcionalidade ganhara status constitucional, aplicável também ao Poder Legislativo ${ }^{21}$. De lá para cá, a força vinculante da proporcionalidade não cessa de se mostrar prestimosa à vigilância, por assim dizer, no tocante à qualidade da conduta do Poder Público, em sentido amplo.

Os avanços doutrinários ${ }^{22}$ e o trabalho jurisprudencial contribuíram, em uníssono, para aperfeiçoar e, acima de tudo, tornar correntes os instrumentos conceituais concretizadores da idéia de que o Poder Público está obrigado a sacrificar o mínimo para preservar o máximo da eficácia direta e imediata dos direitos fundamentais. Claro, a evolução do princípio da proporcionalidade não está terminada. Ao contrário: falta sobretudo efetivar e introjetar a vedação de insuficiência ou omissão. Sob a pressão e a insegurança derivadas do déficit prestacional em matéria de direitos fundamentais, a aplicação do princípio, nesse ângulo, demanda, sem mais tardar, o foco prioritário de todos, notadamente administradores e juízes.

Desde logo, porém, sem prejuízo do potencial promissor, mister extrair da trajetória do princípio o conjunto de critérios que permitem, de maneira segura, aferir, no atinente à responsabilidade extracontratual, a proporcionalidade das condutas estatais. Nesse sentido, há, pelo menos, três subprincípios de cuja confluência depende a aprovação, ou não, no teste da proporcionalidade ${ }^{23}$ :

(a) $\mathrm{O}$ subprincípio da adequação entre meios e fins (Geeignetheit): tal diretriz exige relação de pertinência entre os meios escolhidos pelo legislador ou pelo administrador e o fins colimados pela lei ou pelo ato administrativo. Guardando parcial simetria com o princípio da proibição de excesso (Übermassverbotes), a medida implementada pelo Poder Público precisa se evidenciar não apenas conforme os fins almejados (Zielkonformität), mas, também, apta a realizá-los (Zwecktauglichkeit) ${ }^{24}$. Igualmente se mostra inadequada a insuficiência ou a omissão antijurídica causadora de danos.

21 In ob. cit., p. 130: "Sous le régime de la loi fondamentale, le principe de la proportionnalité des moyes au but est également devenu un principe ayant valeur constitutionnelle et qui s'impose ainsi au respect du legislateur...".

22 Maurer, Hartmut in Droit Administratif Allemand. Tradução de Michel Fromont, Paris: LG.D.J., 1994, p. 248-249: "Les principe de proportionnalité au sens large découle du principe de l'État de droit e doit toujours être respecté. Il ne s'applique du reste pas seulement à l'administration, mais aussi au législateur".

23 A reprovação no teste tríplice da proporcionalidade acarreta o dever de indenizar. Sobre outro teste (NESS test), recomendável conferir, entre outras, a contribuição de Richard Wright e a abordagem clássica de Herbert Hart e Tony Honoré. Vide, mais recentemente, Relating to Responsibility. Editado por Peter Cane e John Gardner. Oxford: Hart Publishing, 2001.

24 Em outras palavras, "la mesure en cause n'est appropriée que si elle est de nature à atteindre à coup sûr le résultat recherché" (Hartmut Maurer in ob. cit., p. 248). 
(b) O subprincípio da necessidade (Erforderlichkeit): o que esse subprincípio impõe não é tanto a necessidade dos fins, porém a justificável inafastabilidade dos meios mobilizados pelo Poder Público. Quando há muitas alternativas, o Estado deve optar em favor daquela que afetar o menos possível os interesses e as liberdades em jogo ${ }^{25}$. É que "o cidadão tem direito à menor desvantagem possível" ${ }^{26}$ (Gebot des geringstmöglichen Eingriffs) ${ }^{27}$, seja por ação, seja por omissão.

(c) O subprincípio da proporcionalidade em sentido estrito: a cláusula da proporcionalidade "stricto sensu" decorre do reconhecimento de que os meios podem ser idôneos para atingir o fim, contudo desproporcionais em relação ao custo-benefício. Sem incorrer em simplificador e ingênuo cálculo utilitário ou mera análise econômica do Direito, a proporcionalidade em sentido estrito indaga pelo "preço a pagar". Vale dizer, faz a conta do lucro e da perda, ao apurar se os ônus não são desmesurados.

Releva destacar que tal tríplice teste deve ser aplicado, indistintamente, para o exame crítico da proporcionalidade das ações e das omissões das pessoas jurídicas de direito público e de direito privado prestadoras de serviço público.

\section{Responsabilidade Extracontratual do Estado e o Princípio da Proporcionalidade. Não se admite o Estado Segurador Universal, tampouco o Estado Omisso}

3.1. O princípio da responsabilidade extracontratual objetiva do Estado pelas condutas omissivas ou comisivas causadoras de lesão antijurídica apresenta-se como um dos pilares do Estado Democrático, sobremodo pelos riscos inerentes à atuação estatal. ${ }^{28}$ Trata-se de proteção que se impõe independentemente de culpa ou dolo do agente causador do dano. Nasce da superação da idéia do Estado como etérea encarnação da vontade geral infalível. A par disso, a consagração, entre nós, da aplicabilidade direta e imediata dos direitos fundamentais $\left(\mathrm{CF}\right.$, art. $\left.5^{\circ}, \S 1^{\circ}\right)$ é um dos argumentos mais robustos contra a teoria segundo a qual não poderia o Estado ser objetivamente responsabilizado por omissões. Com efeito, os requisitos da respon-

25 Como sublinha Maurer. "la mesure appropriée n'est nécessaire que si d'autres moyens appropriés affectant de façon moins préjudiciable la personne concernée et la collectivité ne sont pas à la disposition de l'autorité en cause" (in ob. cit., p. 248).

26 In J. J. Gomes Canotilho in ob. cit., p. 387.

27 Vide Hartmut Maurer in ob. cit., p. 248.

28 Vide Romeu Bacellar Filho in Direito Administrativo São Paulo: Saravin 2605, pj 192-105.

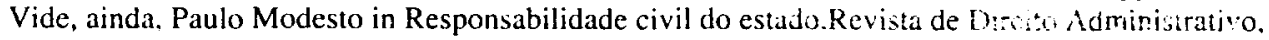
n. 227, p. 291-308, jan./mar. 2002. 
sabilidade estatal objetiva compõem, em grandes traços, uma tríade: a existência de dano material ou imaterial, juridicamente injusto e desproporcional; o nexo causal direto e, finalmente, a conduta omissiva ou comissiva do agente da pessoa jurídica de direito público ou de direito privado prestadora de serviço público, nessa qualidade $^{29}$.

O nexo causal há de ser direto, pois não se perfectibiliza o dano juridicamente injusto se a vítima der causa a ele, ou em caso de força maior, irresistível por definição (diversamente, nesse ponto, do caso fortuito, que pode resultar de causa interna da Administração), nem por fato de terceiro alheio à prestação do serviço público. ${ }^{30}$ Tampouco haverá nexo causal se inviável o cumprimento do dever (princípio da "reserva do possível"). Convém reiterar: não se forma o liame de causalidade -- eis traço importante da presente abordagem - no caso de impossibilidade motivada - consoante o art. 50 da Lei $9.784 / 99$ - do cumprimento de dever, afastada a erronia dos que enveredam para a teoria do risco integral. De mais a mais, se houver culpa parcial da vítima ou, mais tecnicamente, a concausa, então parcial será o dever indenizatório. Em poucas palavras, o dano juridicamente injusto, que prejudica direito ou interesse legítimo (individual ou transindividual), caracteriza-se por ser: (i) certo, (ii) especial (não-eventual), ainda que reflexo e (iii) discrepante dos parâmetros do social e normalmente aceitável. Numa palavra: desproporcional.

Nesse enfoque, os atos "prima facie" lícitos somente formam o liame causal com os eventos danosos se desproporcionais, logo antijurídicos. Em conseqüência, força constatar a superação do vetusto e rígido corte dicotômico entre atos lícitos e ilícitos. No próprio Código Civil, não é certo, aliás, afirmar que haja apenas a responsabilidade por atos ilícitos. Trata-se de regra que comporta exceção. ${ }^{31} \mathrm{De}$ qualquer sorte, para os fins da responsabilização estatal, mister evoluir para a

29 Merece registro: embora, por exemplo, normalmente o assalto de ônibus não forme o liame causal (dada a excludente do "caso fortuito"), se houver participação do agente, gerar-se-á, sim, o dever de indenizar. Vide, a propósito, o REsp 402227/RJ (DJ de 11.04.2005): "I. A 2 a Seção do STJ, no julgamento do REsp n. 435.865/RJ (...) uniformizou entendimento no sentido de que constitui caso fortuito, excludente de responsabilidade da empresa transportadora, assalto a mão armada ocorrido dentro de veículo coletivo. Il. Caso, entretanto, em que a prova dos autos revelou que o motorista do ônibus era indiretamente vinculado a dois dos assaltantes e que se houve com omissão quando deixou de imediatamente buscar o auxílio de autoridade policial, agravando as lesões de ordem física, material e moral acontecidas com a passageira, pelo que, em tais circunstâncias, agiu com culpa a ré, agravando a situação da autora, e por tal respondendo civilmente, na proporção desta omissão. III. Recurso especial conhecido e parcialmente provido."

30 Importante exceção encontra-se na Lei $10.744 / 2003$, consoante a qual fica a União autorizada, na forma e critérios estabelecidos pelo Poder Executivo, a assumir despesas de responsabilidade civil perante terceiros na hipótese da ocorrência de danos a bens e pessoas, passageiros ou não, provocados por atentados terroristas, atos de guerra ou eventos correlatos, ocorridos no Brasil ou no exterior, contra aeronaves de matrícula brasileira operadas por empresas brasileiras de transporte aéreo público, excluídas as empresas de táxi aéreo. Mais: no art. $4^{\circ}$, consta que pode ser cancelada a assunção. De fato, à evidência, trata-se mais de assunção do que propriamente de dano injusto causado pelo Estado.

31 Vide, a propósito, a hipótese prevista no art. 188 do Código Civil. 
apuração das condutas públicas (comissivas ou omissivas) sob o crivo do tríplice critério da proporcionalidade..$^{32}$

Pelo exposto, inadiável a incorporação do entrelaçamento fecundo entre os princípios da proporcionalidade e da responsabilidade objetiva do Estado, este último consagrado na Lei Fundamental, no art. $37, \S 6^{\circ}$. Dessa conexão, brotam as seguintes principais assertivas:

(a) Nítida a obrigação objetivamente imposta ao Estado e aos prestadores de serviços públicos de reparar ou compensar os prejuízos anômalos, determináveis e

32 De acordo com Ernst Forsthoff in Lehrbuch des Verwaltungsrechts. München: C. H. Beck'sche Verlag, 1973, pp. 359 e ss., as grandes transformações conhecidas pela teoria da responsabilidade civil do Estado se processaram "no silêncio da lei" ("unter dem Schweigen des Gesetzes"). O alargamento das funções do Estado provocou mudanças nas relações entre Poder Público e indivíduo, as quais, por sua vez, promoveram marcantes alterações na tradicional concepção acerca de responsabilidade civil do Estado. Condições sociais e políticas inéditas reclamaram, primeiro da jurisprudência, depois na legislação, soluções ajustadas às novas circunstâncias. $O$ marco inicial dessa troca de paradigma ocorreu com o chamado "arrêt Blanco", ao qual se liga o surgimento da teoria da "faute du service public", cuja superação, passado algum tempo, resultou na célebre concepção do "risco administrativo". Adotando linha de pensamento semelhante, Paul Duez e Guy Debeyre sustentam: "La responsabilité de la puissance publique est oeuvre du Conseil d'État qui là édifiée en toute liberté, en dehors des textes législatifs. Sans doute il y a bien des lois qui consacrent formellement la responsabilité de la puissance publique, certaines mêmes sont anciennes, mais elles ne visent que des cas particuliers. La théorie général de la responsabilité n'est pas incluse dans ces textes. Elle se trouve dans les arrêts du Conseil d'État" (Traité de Droit Administratif. Paris: Librairie Dalloz, 1952, pp. 417-418). Sobre o princípio da responsabilidade do Poder Público, vide, ainda, André de Laubadère in Manuel de Droit Administratif. Paris: L.G.D. J., 1976, p. 125 e Marcel Waline in Précis de Droit Administratif. Paris: Éditions Montchrestien, 1969, pp. 519-594. A propósito especificamente da natureza juspublicista do instituto, já advertia Santi Romano in Corso di Diritto Amministrativo. Padova: CEDAM, 1932, p. 306: " $E$, in verità, è da riconoscersi che, nel campo del Diritto Amministrativo, acquistano un particolare rilievo, in modo da divenire fondamentali, alcuni principii che sono o ignoti al Diritto Privato, o vi ricorrono raramente o in esso hanno una importanza soltanto secondaria". Vide, sobre a adoção do critério objetivo, o clássico José de Aguiar Dias in Da Responsabilidade Civil, vol. 2, Rio: Forense, 1944, p. 33. No que diz com a evolução da idéia da responsabilidade do Estado, bem descreve as fases (ob. cit., p. 154) da irresponsabilidade ("noção de fundo essencialmente absolutista"), civilística ("de fundo individualista") para e publicista ("onde se afirma a predominância do Direito Social"). Já elucidava o igualmente clássico Amaro Cavalcanti, acerca da soberania estatal, que esta "significa sem dúvida poder supremo, isto é, a função mais elevada e compreensiva de todas as mais, que se manifestam na ordem jurídica; mas não que ela seja absoluta, ou menos sujeita ao Direito, do que qualquer outra forma de função social" in Responsabilidade Civil do Estado, tomo I, Rio de Janeiro: Borsoi, 1956, p. XII. Ainda com extrema atualidade, convém lembrar que, para Léon Duguit, a difusão da responsabilidade civil do Estado, por assim dizer, caracteriza o desaparecimento da noção de "puissance publique": "On parle, à l'heure actuelle, de la transformation du Droit Public; on a raison. Cette transformation est rapide e profonde; il faudrait être aveugle pour na pas l'apercevoir; et cette transformation, elle apparaît d'une manière particulièrement caractéristique (...) surtout dans la responsabilité de plus en plus grande de l'État, reconnue par une jurisprudence constante à propos du fonctionnement de tous les services publics" in Traité de Droit Costitutionnel, vol. II, Paris: Ancienne Librairie Fontemoing \& Cie. Éditeurs, 1928, p. 40). Sobre a evolução, vide Louis Josserand in "Evolução da Responsabilidade Civil", Revista Forense, vol. 86, p. 52 e ss. 
especiais. Noutro dizer, tais entes devem arcar com os riscos inerentes à conduta comissiva ou omissiva. Daí segue que a vítima, em razão de sua presumida vulnerabilidade (por força da Constituição), não tem o ônus de provar a culpa ou o dolo do agente. Mostra-se bastante que nada exclua, no curso do processo, a formação do nexo causal direto e "imediato" entre a conduta omissiva ou comissiva e o dano. Conseguintemente, sem adotar a teoria do risco integral, o nosso sistema acolheu, no citado dispositivo da Constituição, a responsabilidade extracontratual objetiva das pessoas jurídicas prestadoras de serviço público, integrantes ou não da estrutura da Administração, conforme a causalidade proporcional, que jamais deve ser entendida como a imputação do dever de indenizar todo e qualquer dano. Tal intelecção mostrar-se-ia conducente ao destempero do risco absoluto. Ao revés, a teoria do risco administrativo aqui adotada significa que as aludidas pessoas jurídicas arcam com o dever de reparar ou compensar os danos juridicamente injustos e a vítima, em razão de sua presumida vulnerabilidade, sem o ônus de provar a culpa ou o dolo dos agentes públicos em sentido amplo. Contudo, trata-se de presunção "juris tantum" da existência do nexo de causalidade, resguardadas as excludentes em contrário.

(b) Na sistemática brasileira, não se vai ao ponto de preconizar a indenização por danos alheios à Administração, exceto quiçá no caso de danos nucleares (CF, art. 21, XXIII, "c"), a despeito de a disciplina infraconstitucional admitir excludentes. O certo, no entanto, inclusive ao se tratar de eventos da natureza, é que não cabe à vítima a tarefa de provar a individualização subjetiva da culpa do agente estatal.

(c) Impende ressaltar a opção do constituinte originário quanto à responsabilidadeproporcional e objetiva das pessoas jurídicas de direito privado prestadoras de serviço público, reforçada pela legislação infraconstitucional (sobretudo pela Lei 8.987/95), sem que a indeclinável fiscalização da prestação do serviço exclua ou diminua tal responsabilidade, nem se embaralhem as atividades delegadas com as propriamente privadas. De resto, em face da titularidade do Poder Público no tocante a serviços universais delegados, mostra-se inescapável a responsabilidade subsidiária (não solidária, em regra) do Estado.

(d) Mostra-se crítico efetuar o contraste do comando constitucional com os arts. 43 (menos abrangente), 186 e 927, do Código Civil, em face da teoria do risco administrativo, bem distinta de outras teorias, tais como a do risco-criado ou do risco-proveito ${ }^{33}$. Além disso, segundo a intelecção temperada pelo princípio da proporcionalidade, toda vez que se formar, sem interrupção, o nexo causal (direto e "imediato") entreos agentes públicos, nessa qualidade, e o dano injusto causado a terceiros (dano desproporcional), haverá o dever de indenizar, distribuído o ônus da prova no que concerne à excludente (parcial ou total) ao Poder Público ou, se for o caso, aos delegados da execução indireta dos serviços públicos. ${ }^{34}$

33 Sobre o tema, vide lição valiosa de Eugênio Facchini in " Da Responsabilidade Civil no novo Código" in O Novo Código Civil, Obra coletiva, Porto Alegre: Livraria do Advogado, 2003, pp. 151-198.

34 Bem observa René Chapus in Droit Administratif Jénéral, tome 1, 13* ed., Paris: Monthchrestien, 1999, 1193: “La responsabilité de la personne à qui réparation est demandée ne peut être 
(e) Mister aduzir que, sem lançar mão do problemático conceito de "culpa anônima" (não-individualizável) em sede de responsabilidade pelas condutas omissivas do Poder Público lato sensu, a falta do cumprimento dos deveres estatais gera o dever de indenizar, salvo se presentes as excludentes do nexo causal direto, de modo que se faz presumida a existência do liame causal, salvo prova excludente em contrário. Em outras palavras, a omissão também pode ser causa de dano anômalo e injusto, sem enquadrá-la, com a devida vênia de eminentes pares, como simples condição para o evento danoso, nem vê-la como mera situação propiciatória. A omissão, em termos mediatos, sempre traz, por assim dizer, o frustrado "princípio ativo" do dever estatal não-cumprido. Assim, se se cuidar de omissão determinada ou determinável, produtora de nexo causal direto - em razão do descumprimento de dever positivo - o ônus da prova das excludentes incumbe às pessoas jurídicas de direito público e de direito privado prestadoras de serviço público, inexistindo diferença apreciável no cotejo com os atos comissivos, ainda que evidentes as peculiaridades. Dito de modo frontal, deve-se admitir a inversão do ônus da prova, em benefício da suposta vítima, tanto por ações como por omissões. Ao Estado incumbe a prova da exclusão do nexo de causalidade, independentemente da indagação de culpa ou dolo, individual ou "anonimamente", sem que se converta em "segurador universal", porque não se acolhe, nem de longe, a teoria do risco integral. Bem por isso, admite-se o afastamento do nexo causal direto e "imediato", a título de preservação da proporcionalidade, nos casos de impossibilidade do cumprimento de dever. Mais: a rigor, na leitura sustentada, mostra-se despicienda a indagaçãoadstrita à noção de omissão voluntária, negligência ou imprudência, nos termos do Código Civil, art. 927, "caput". De fato, à semelhança do que sucede com as condutas comissivas, a responsabilidade extracontratual do Estado por omissões haverá de ser proporcional e objetiva, com a inversão do ônus da prova que não se confunde com a mera presunção de culpa do Poder Público. ${ }^{35}$ Enfatize-se, pois, que não há necessidade de subjetivação da culpa e que o relevante é constatar o nexo causal direto (causalidade proporcional).

engagée que si le fait qu'on lui impute a été cause ("diretcte", insistent les arrêts) du préjudice". Em nosso sistema, adota-se a teoria do dano direto e "imediato", sem endosssar a teoria da equivalência das causas. Vide, a respeito, Mário Júlio de Almeida Costa in Direito das Obrigações. Coimbra: Coimbra ed., 1984, p. 516.

35 Para Marçal Justen Filho in ob.cit., o tratamento jurídico dos atos omissivos e comissivos é único e equivalente: a responsabilização civil dependerá da infração a um dever jurídico de diligência, que importa a objetivação do elemento subjetivo da conduta (p.802). Defende, no entanto, a presunção de culpabilidade derivada da existência de um dever de diligência especial. (p.803) De minha parte, defendo mais propriamente a presunção da existência do nexo causal, tanto nas ações como nas cmissões, subordinada às excludentes, com inversão do ônus da prova. O resultado é parecido, com a diferença de que mantenho, na minha abordagem, intacto o caráter subjetivo da responsabilidade do agente, isto é, sem a objetivação da culpa, diversamente do que faz o ilustre e estimado colega (p. 812), em seu valioso tratamento do tema. 
3.2. Posto isso, eis a consolidação dos argumentos aptos a corroborar tais assertivas favoráveis à responsabilidade proporcional e objetiva do Estado, tanto por ações como por omissões.

Em primeiro lugar, ao que tudo indica, não dimana do art. 37, parágrafo $6^{\circ}$, da $\mathrm{CF}$, nenhuma rigidez dicotômica, no atinente ao regime da responsabilidade do Estado no tocante às condutas omissivas ou comissivas dos agentes públicos lato sensu, mormente ao se acolher a noção de causalidade que não reduz a omissão à mera "conditio" para o dano, por assimilá-la como possível elemento integrante e juridicamente decisivo na série causal de eventos injustos.

Segundo: não se cogita de defender a culpa presumida, mas a inversão do ônus da prova do nexo de causalidade, toda vez que se discutir o dano injusto causado por uma conduta omissiva ou comissiva, sem prejuizo das excludentes trazidas pelo Estado, dada a inversão defendida. A propósito, de acordo com a teoria do risco administrativo, revista à luz da proporcionalidade, melhor se assimila a noção de causalidade idônea para produzir o resultado danoso. Cumpre ao Poder Público, dada a vulnerabilidade da vítima, constitucionalmente consagrada, o encargo de mostrar a falta de sequiência da cadeia causal, oportunidade que não simplesmente põe entre parênteses, mas afasta, por inteiro, a equivocada responsabilização integral.

Em terceiro lugar, a Constituição Federal, no art. $5^{\circ}$, parágrafo primeiro, exige a aplicabilidade direta e imediata dos direitos fundamentais (inclusive os sociais, relacionados a serviços públicos), motivo pelo qual deve-se escolher a interpretação apropriada ao combate à maciçae insofismável omissão do Estado brasileiro no atendimento às necessidades existenciais mínimas dos cidadãos. Nessa linha, induvidoso que a técnica da responsabilização objetiva desponta como a mais aconselhável, perante a constatação de que temos um Estado que oscila entre dois pólos: excessivo e omissivo, com freqüência inaudita. Desproporcional em ambas as situações.

Quarto argumento: o princípio da proporcionalidade veda excessos e, simultaneamente, inoperâncias (omissões), de sorte que a omissão se apresenta, em si, violadora do dever de agir proporcional. Cumpre assimilar que, uma vez consubstanciada a violação, não há que perquirir subjetiva ou psiquicamente sobre a responsabilidade, inclusive no caso das condutas omissivas, impondo-se a mais pronta e plena justiça retificadora.

Em quinto lugar, não precisa ser utilizada a distinção entre omissão e falha de vigilância em contexto de guarda de pessoas ou de coisas perigosas, como se apenas em relação a essas houvesse responsabilidade estatal objetiva, pois não se vislumbra uma distinção de fundo entre tais espécies de omissão. Logo, melhor é aplicar a responsabilidade objetivamente mitigada pelo princípio da proporcionalidade para toda e qualquer omissão efetivamente causadora de dano injusto, evitados, é claro, os excessos que transformariam o Estado em segurador de riscos exclusivamente privados.

Em sexto lugar, a técnica da responsabilização proporcional é a que mais se coaduna com o imperativo enfrentamento parcimonioso e prudente, em tempo hábil e plausível, dos danos causados pela ausência tempestiva de medidas de prevenção ou de precaução, na iminência da formação do liame causal direto. Aliás, mais do 
que a prevenção, força que o princípio da precaução progrida para se transformar em diretriz cogente e aplicável às relações administrativas em geral. ${ }^{36}$ Eis poderosa razão para esposar a responsabilidade objetiva e proporcional do Estado no tocante às condutas omissivas, vale dizer, para estimular as providências destinadas a prevenir ou precaver no devido tempo. De passagem, observe-se que, na seara ambiental, a responsabilidade do Estado não é meramente subsidiária, mas solidária - como poluidor indireto $-{ }^{37}$, mas não se deve adotar a teoria do risco integral, sequer nesta província. Aqui, nos termos do princípio da prevenção, quando o mal for conhecido, devem-se tomar as medidas aptas a evitá-lo, sob pena de omissão objetivamente causadora (não mera condição) de dano injusto, à vista da inoperância estatal (insuficiência do agir exigível), porém admitidas as excludentes. Já nos termos do princípio da precaução, quando se tratar de mal altamente provável, conquanto não definido, a efetivação do dano deverá acontecer e, só então, haverá o nexo direto gerador da obrigação de reparar. O Estado tem o dever, desde logo, de tomar as medidas cabíveis, sob pena de responder objetivamente pelos danos injustos, uma vez concretizados e, novamente, admitidas as excludentes. Outra vez, resulta cristalino que se o prejuízo ocorrer, a omissão integrará a série causal do dano injusto.

Em sétimo lugar, sem pretender argumentação ad baculum ${ }^{38}$, inquestionável que, na vida real, a subjetivista perquirição da culpa, nos casos de omissão, pode infelizmente representar a persistência de dano injusto sem a devida e tempestiva reparação, à vista das crônicas omissões do Estado brasileiro, que ainda não respeita, de maneira satisfatória, a aplicabilidade direta e imediata, no núcleo essencial, dos direitos fundamentais.

Por último, sem querer efetuar argumentação com base em casos paradigmáti$\cos ^{39}$, útil referir o julgamento do Supremo Tribunal Federal, que consagra, de modo confluente, com pequenas diferenças de justificação, o enfoque aqui defendido: "Os elementos que compõem a estrutura e delineiam o perfil da responsabilidade civil objetiva do Poder Público compreendem (...) a causalidade material entre o eventus damni e o comportamento positivo (ação) ou negativo (omissão) do agente público (...) O Poder Público, ao receber o estudante em qualquer dos estabelecimentos da

36 Sobre o princípio da precaução, na área ambiental, vide Paulo Affonso Leme Machado in Direito Ambiental Brasileiro, São Paulo: Malheiros, 2004, p. 57: "a precaução caracteriza-se pela ação antecipada diante do risco ou do perigo". E mais: não se trata de simples prevenção (também necessária, é claro), mas de dever, nos moldes do Princípio 15 da Declaração do Rio de Janeiro de 1992. Para não incorrer em demasias, vide o alerta de Cass Sunstein in Beyond the Precautionary Principle. University of Pennsylvania Law Review 1003 (2003). Ainda sobre prevenção, em matéria ambiental, vide o art.54, parágrafo terceiro da Lei 9.605/98 e, sobre precaução, vide o art. 29 da Lei 6.938/81. Vide, também, a Carta do Ambiente, aprovada pelo Parlamento francês, em fevereiro de 2005 .

37 Vide arts. $3^{\circ}$ e 14 da Lei 6.938/81. Vide, nessa linha, REsp 604725/PR e REsp 28222/SP.

38 Argumento ad baculum: "defender uma conclusão destacando as terríveis consequeiências de não acreditar nela" in Dicionário Oxford de Filsofia, de Simon Blackburn. Rio: Jorge Zahar Editor. $1997,24$.

39 Até porque seria possível uma coleção de contra-exemplos na matéria. 
rede oficial de ensino, assume o grave compromisso de velar pela preservação de sua integridade física, devendo empregar todos os meios necessários ao integral desempenho desse encargo jurídico, sob pena de incidir em responsabilidade civil pelos eventos lesivos ocasionados ao aluno. A obrigação governamental de preservar a intangibilidade física dos alunos, enquanto estes se encontrarem no recinto do estabelecimento escolar, constitui encargo indissociável do dever que incumbe ao Estado de dispensar proteção efetiva a todos os estudantes que se acharem sob a guarda imediata do Poder Público nos estabelecimentos oficiais de ensino." ${ }^{40}$ Merece realce que tal julgamento, embora não isolado, sugere um novo horizonte, no campo da responsabilidade estatal por omissão, na linha da advogada proteção mais efetiva dos direitos fundamentais. ${ }^{41}$

Para evidenciar que não se trata de creatio ex nihilo, cite-se outro caso elucidativo do próprio Supremo Tribunal ${ }^{42}$ : "Responde o Município pelos danos causados a terceiro em virtude da insuficiência de serviço de fiscalização (...)". Ora, bem de ver, desnecessário provar, em situações desse jaez, culpa ou dolo dos agentes e cumpre ao Poder Público desfazer o nexo causal, tudo de acordo com a teoria do risco administrativo, redimensionada dialeticamente, sob o prisma da proporcionalidade. Ainda: para evidenciar que a jurisprudência, a pouco e pouco, emite sinais de rejeitar omissões injustificáveis, convém ter presente o julgamento do Mandado de Injunção ${ }^{43}$, no qual o Supremo Tribunal entendeu presente a mora do Congresso Nacional e "desnecessária a renovação de notificação ao órgão legislativo que, no caso, (....) incidiu objetivamente na omissão do dever de legislar, passados quase quatorze anos da promulgação da regra que lhe criava tal obrigação." Ao mesmo tempo, assegurou "aos impetrantes o imediato exercício do direito a esta indenização, nos termos do direito comum." Outro tanto se pode dizer quanto ao descumprimento danoso de ordem judicial, hipótese em que a Suprema Corte acolheu - nominalismos à parte - a responsabilidade, nos moldes aqui preconizados. ${ }^{44}$ Nesse diapasão, não por acaso, caem como folhas de outono as dúvidas quanto à responsabilidade objetiva no caso de guarda de pessoas ou bens, hipótese em que o descumprimento do dever (inoperância) faz presumido o nexo causal, até prova em contrário. Portanto, os sinais de mudança de atitude interpretativa, apesar de nuançados, felizmente se acumulam..$^{45}$

40 RExt 109.615-RJ, Relator Min. Celso de Mello.

41 Claro que há casos em que o omissão não forma o liame causal. Vide, para exemplificar, o RExt 220999/PE, Rel. para o Acórdão, Min. Nelson Jobim: “ Não há como se extrair da Constituição a obrigação da União em oferecer transporte fluvial às empresas situadas à margem dos rios. A suspensão da atividade não se constitui em ofensa a dever ou direito." Ora, nesse caso, não houve dano juridicamente injusto e merecedor da indenização. Força convir, seria abertamente desproporcional admiti-lo.

42 RExt 180602, Rel. Min. Marco Aurélio.

43 MI 562/RS, Relatora Min. Ellen Gracie Northfleet.

44 Para exemplificar, vide RExt 283989/PR.

45 Bem a respeito: “Caracteriza-se a responsabilidade civil objetiva do Poder Público em decorrência de danos causados, por invasores, em propriedade particular, quando o Estado se omite no 
À base, pois, dessa família de argumentos, emerge, límpida e consistente, a responsabilidade proporcional e objetiva por açãao ou omissão do agente estatal, em sentido largo, de sorte que, mantida a atitude cautelosa e avessa a automatismos ${ }^{46}$, a responsabilidade do Estado, nos casos de omissão, não mais deve fugir da responsabilização objetiva. Tal não significa que a sociedade deva arcar com os danos oriundos de riscos exclusivamente atribuíveis às vítimas ou inerentes a seus negócios. Numa fórmula, o Estado não deve ser segurador universal, tampouco omisso ou descumpridor dos deveres defensivos e prestacionais ou positivos.

No prisma proporcional (entendido como "norma sobre norma"), o Poder Público terá sempre o ensejo de evidenciar a não-configuração do liame de causalidade, mas de nada valerá a simples alegação da inocorrência de culpa ou dolo, pois, inclusive nos casos de omissão, impõe-se a prova estatal da exclusão do nexo.

O Estado brasileiro, em última análise, tem o dever de zelar pela eficácia direta e imediata dos direitos fundamentais, punível a omissão despida de motivos plausíveis e, sobretudo, aquela derivada da macunaímica preguiça. Portanto, o descumprimento de deveres estatais objetivos mostra-se injustamente danoso e ofensivo à Constituição. Afinal, os direitos fundamentais vinculam de modo cogente e, vez por todas, possuem o primado nas relações administrativas. Em suma, independe de culpa ou dolo a configuração do nexo causal, na leitura proposta do art. $37, \S 6^{\circ}$ da $\mathrm{CF}$, toda vez que a ação ou a inoperância do Estado prejudicar o âmago dos direitos fundamentais, sem que resultem provadas, pelo Poder Público, as excludentes. ${ }^{47}$

\section{Conclusões}

Tudo considerado, a teoria do risco administrativo desponta profundamente enriquecida na preconizada conexão com o princípio da proporcionalidade. Concluise, nessa perspectiva, que:

cumprimento de ordem judicial para envio de força policial ao imóvel invadido." (RExt 283.989) 46 Contra automatismos interpretativos, vide, por obséquio, meu A Intepretação Sistemática do Direito, ob.cit..

47 Vide RESP 246.758/AC. Rel. Min. Barros Monteiro. Trata-se de caso emblemático da vítima fatal em razão de desabamento de poste, resultando comprovado o estado de má conservação. Ademais, a responsabilidade da empresa da energia elétrica, diz o relator, é objetiva. Merece parcial transcrição o voto: "No caso, além de comprovada a culpa cabal da empresa acerca do acidente fatal, há a considerar-se que a sua responsabilidade é objetiva, consoante deflui do disposto no art. 37, par. $6^{\circ}$ da Constituição da República. Bastava, pois, ao autor demonstrar a existência do fato para haver a indenização pleiteada, ficando a cargo da ré o ônus de provar a causa excludente alegada, o que, segundo as instâncias ordinárias, não logrou ministrar. Do quanto foi exposto, não conheço do recurso." Vide mais: "Caso em que resultaram configurados não apenas a culpa dos agentes públicos na custódia do preso - posto que, além de o terem recolhido à cela com excesso de lotação, não evitaram a introdução de arma no recinto - mas também o nexo de causalidade entre a omissão culposa e o dano. (...) Recurso não conhecido.(STF. Primeira Turma. RExt 170014/SP. DJ 31/10/1997, Relator Min. llmar Galvão) 
(I) O Estado brasileiro deve ser proporcionalmente responsabilizado, pois toda e qualquer quebra nuclear da proporcionalidade faz com que a ação ou omissão deixe de ser tida como normal e aceitável. Assim, as condutas comissivas ou omissivas, presente o nexo causal com o evento danoso e certo, serão sempre antijurídicas. no mínimo por violarem o princípio da proporcionalidade.

(II) Ao enunciar tais idéias, longe de considerá-las peremptórias, pretende-se contribuir para uma solução sistemática que atenda equilibradamente a princípios que se devem conciliar. Necessário é, de conseguinte, ao tratar da responsabilidade extracontratual do Estado, apagar os derradeiros vestígios do regalismo, de modo a cuidar dos interesses existenciais legítimos dos cidadãos, na marcha para a perfomance do Estado apto a honrar os seus poderes-deveres, máxime o de salvaguarda da Constituição, evitando ou reparando prontamente os danos juridicamente injustos.

(III) Nesse prisma, uma vez cristalizada a antijuridicidade (ação ou omissão anômala e desproporcional), haverá o nexo causal e o dever de indenizar: não há motivo para indagar sobre a culpa ou o dolo do agente. massomente acerca da antijuridicidade e de sua extensão, na violação ao princípio da proporcionalidade, em sua duplaface: vedação de excessos e proibição de inoperâncias ou omissões. Configurada a violação, existirá o dano anômalo, ainda que a conduta do agente possa ser catalogada como "lícita". Eis a saída proporcional para as legítimas preocupações com relação ao objetivismo extremado. Dito em outros termos, com a devida prudência, a teoria do risco administrativo, reexaminada em harmonia com o princípio da proporcionalidade, conduz à responsabilidade adequada, necessária e proporcional em sentido estrito, propensa a viabilizar a eficaz reparação, bem como a tempestiva prevenção e, se for o caso, a precaução. Tudo para que cessem os famigerados danos provocados por ações e omissões antijurídicas. Em última instância, não se quer nem o Estado arbitrário e excessivo, nem o Estado brasileiro descumpridor dos seus deveres e gravemente omisso. Quer-se. com o firme anelo, ver, no século em curso, os princípio da proporcionalidade e da responsabilidade compreendidos e aplicados, de maneira sistemática, fundamentada e consistente, a favor da eficácia direta e imediata dos direitos fundamentais. 


\section{O Direito de Assistência Humanitária}

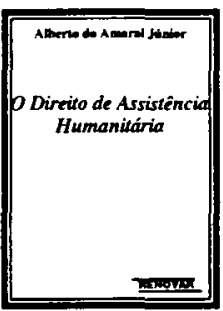

\author{
Alberto do Amaral Junior \\ Ref. 0427 \\ Brochura \\ 312 págs. \\ Form. $13.5 \times 21$ \\ 2003 \\ ISBN 85-7147-340-4
}

A análise empreendida parte da função desempenhada pelo princípio de não-intervenção na ordem internacional de Westfalia. Regra de coexistência entre os estados europeus, com amplitude geográfica limitada, o princípio de não-intervenção é corolário da soberania estatal, reproduzindo a crença de que a estabilidade internacional depende da tolerância manifestada em relação ao que se passa no âmbito interno dos estados.

\section{O Prejuizo na Fraude contra Credores}

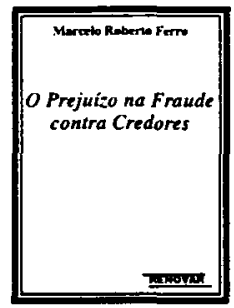

\section{Marcelo Roberto Ferro}

Ref. 0161

Brochura

200 págs.

Form. $13,5 \times 21$

1998

ISBN 85-7147-074-X

0 conceito de eventus damni representa tema de grande relevo doutrinário e prático acerca da fraude contra credores. 0 autor enfrenta questões historicamente controvertidas sobre o tema, desde a anulabilidade da venda de imóvel por justo preço, pelo devedor, até a legitimidade dos credores privilegiados, dos credores posteriores ao ato atacado e dos credores titulares de créditos sob condiçāo suspensiva e a termo para o exercicio da ação pauliana.

\section{Os Novos Paradigmas da Familia \\ Contemporânea \\ Uma Perspectiva Interdisciplinar}

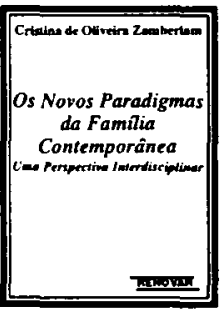

Cristina de Oliveira Zamberlam

Ref. 0322

Brochura

176 págs.

Form. $13.5 \times 21$

2001

ISBN 85-7147-194-0

A observação da familia atual leva à percepção de um grupo confuso, muitas vezes contraditório, oscilando entre dois distintos modelos - hierarquizado e igualitário. A modernidade pôs a lamilia em xeque, pois a evoluçāo vertiginosa da sociedade levou a família contemporânea a refazer seus alicerces. Porém, apesar das pressões sem precedentes, a família está e sempre esteve no centro da civilização e da vida.

\section{Pertis do Direito Civil Introduçāo ao Direito Civil Constitucional}

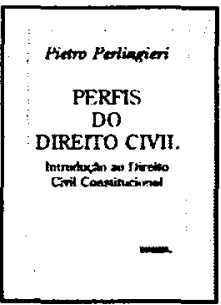

\section{Pietro Perlingien}

Ref. 0135

Brochura

369 págs.

Form. $16 \times 23$

$2002 / 2^{2} \mathrm{ed}$

ISBN 85-7147-038-3

Um clássico da moderna produção italiana, vem recebendo entusiástica acolhida no Brasil. Esta obra, que propōe uma releitura de toda a legislação civel à luz das normas - regras e princípios - insertos na Lei Maior, é a apresentação ideal ao principal artífice da escola civil-constitucional, que tanto vem contribuindo para a renovação dos estudos jurídicos em nosso país. Indispensável. 